\title{
ONLINE MEDICAL EDUCATION AMID THE LOOMING THREAT OF COVID-19
}

\author{
Muhammad Saaiq \\ Assistant Professor Plastic surgery and Burns, \\ Pakistan Institute of Medical Sciences \\ Islamabad \\ Ikramullah \\ Assistant Professor Institute of kidney \\ diseases Hayatabad, Peshawar
}

In the aftermath of COVID-19 pandemic, the health professions education (HPE) has witnessed a powerful paradigm shift. The lock downs, social distancing and precautionary measures against the potential spread of corona virus, all strongly favor the online instructional formats ${ }^{1}$. The online learning carries an enormous untapped potential for the developing countries like Pakistan. It can strongly supplement the on-campus face to-face learning sessions. It can be easily applied to the entire continuum of HPE, which includes undergraduate medical education, postgraduate medical education and continuing professional development ${ }^{2}$. The online learning offers certain added advantages. For instance it is student centered and promotes self-directed learning. It is convenient and low cost. It allows for flexibility of schedules as well as instructional formats ${ }^{3}$.

In the online learning sessions, the health professions educators carry some added responsibilities. For instance they should anticipate and hence circumvent issues such as system failures, communication blocks, lack of technical know-how on part of the participants and the possibility of cognitively overloading the participants. These inhibitors adversely affect the satisfaction as well as learning of the participants. The online course designers should make every possible effort to minimize these issues ${ }^{4}$. High level of motivation of the learners constitutes the cornerstone of any successful educational activity. An enthusiastic teacher is equally crucial for its success. These principles apply even more to the online instructional formats. At the very outset, the teacher should skillfully instill eagerness among participants towards achieving the desired learning objectives. He should carefully address the leaning needs of his students. During the activity, he should maintain a positive emotional milieu. At the conclusion, he should reinforce the learning through positive feedback and pointing out the competencies achieved. Additionally he should promote active interactive learning as well as produce communities of learners ${ }^{5}$.

The online learning environment can be enhanced by efficient use of the available information technology tools alongside abiding to the basic principles of andragogy. The learning experience can be amplified by paying attention to fine details regarding the learning needs and preferences of the learners, design and delivery of the learning material and characteristics of the learners ${ }^{6}$. In the online learning sessions, certain added efforts are also required on part of the learners. For instance, they should have extra commitment and computer skills. They should develop positive attitude towards modern ways of learning and teaching. They should be tech savvy and employ the new technologies in their routine practices ${ }^{7}$.

We conclude that the online learning sessions efficiently supplement the traditional face-to-face contact sessions. When refined further, they can even replace the contact sessions. The future medical teachers should not be mere role models and facilitators of learning but also the architects of more yielding online educational programs ${ }^{8}$.

\section{REFERENCES:}

1. Anwar A, Mansoor H, Faisal D, Khan HS. E-Learning amid the COVID-19 lockdown: standpoint of medical and dental undergraduates. Pak J Med Sci 2020;37(1). 
2. Emery A. E-lectures and online learning: Not a replacement for live teaching. Med Teach. 2017;39(12):1292.

3. Cook DA, Dupras DM. Flexible teaching for inflexible schedules: an online resident curriculum in acute ambulatory care. Med Teach. 2003;25(3):330-1.

4. Cook DA, Dupras DM, Thompson WG, Pankratz VS. Web-based learning in resident continuity clinics: a randomized, controlled trial. Acad Med. 2005;80(1):90-7.

5. Collison G, Elbaum B, Haavind S, Tinker R. Facilitating online learning: effective strategies for moderators. Madison, USA: Atwood Publishing; 2000.

6. Cook DA, Dupras DM. A practical guide to developing effective web-based learning. J Gen Intern Med. 2004;19(6):698-707.

7. O'Doherty D, Dromey M, Lougheed J, Hannigan A, Last J, McGrath D. Barriers and solutions to online learning in medical education - an integrative review. BMC Med Educ. 2018;18(1):130.

8. Chumley-Jones HS, Dobbie A, Alford CL. Web-based learning: sound educational method or hype? A review of the evaluation literature. Acad Med. 2002;77(10 suppl):S86-93.

LICENSE: JGMDS publishes its articles under a Creative Commons Attribution Non-Commercial Share-Alike license (CC-BY-NC-SA 4.0). COPYRIGHTS: Authors retain the rights without any restrictions to freely download, print, share and disseminate the article for any lawful purpose. It includes scholarly networks such as Research Gate, Google Scholar, LinkedIn, Academia.edu, Twitter, and other academic or professional networking sites. 